\title{
ACHIEVING COCONUT SUPPLY RELIABILITY THROUGH RESEARCH-BASED CROP NUTRITION MANAGEMENT OF COCONUT FARMS IN THE PHILIPPINES
}

\author{
By \\ Severino S. Magat, $\mathrm{PhD}^{1}$
}

\begin{abstract}
A critical review of the PCA's extensive $R \& D$ findings, and field-extension experience, particularly, the Small Coconut Farms Development Project or SCFDP (1990 - 1998) was done. The analysis revealed several key points relevant to pursue a sustained coconut rehabilitation of 750,000 hectares (ha.)@a 5-year cycle in the wet and intermediate growing zones with judicious fertilization (crop nutrition management).

These major points are: (1) at least 2 million (M) ha of current stands of coconut ( more than $95 \%$ local tall varieties) have been suffering from widespread multi-deficiency of plant nutrients such as nitrogen, chloride, sulfur, potassium, phosphorus and micronutrients like boron, zinc and copper; (2) as such, this is a major growth and yield-limiting factor that limits the average annual coconut productivity (40 nuts tree or 1 ton copra/ha); (3) the average performance (1992-95) of the SCFDP farms showed that coconut productivity increased to 91 nuts/tree (from 35 nuts) or to 3.01 tons copra/ha (from only 0.94) after at least 3 years of regular annual application of fertilizers; in 1998 ( post-rehabilitation of 3 years) yields dropped to 70 nuts/tree or 2.21 copra/ha; (4) onwards to year 2010, without management, these SCFDP farms are predicted to further drop to 25.9 nuts/tree ( 0.70 ton copra/ha/yr), based on the estimate 8-9\% annual reduction rate of yield; and (5) apparently, nationwide, the SCFDP experience had shown that the soil nutrient-poor coconut farms are only capable of producing only about 1/3 of its achievable yield of $85-120$ nuts/tree ( $2-3$ tons copra/ha), annually.

The Malaysian success in optimizing the genetic potential of oil palm ( average of 3.8 tons of palm oil /ha /yr or 24-32 tons fresh fruit-bunch/ha/yr) resulted in its global supply of $10.70 \mathrm{M}$ tons of palm oil plus $1.42 \mathrm{M}$ tons of palm kernel oil from its $2.91 \mathrm{M}$ ha of oil palm crop in 2001. In contrast to the production of coconuts in Philippines in the same year of only $2.54 \mathrm{M}$ tons (copra terms) from its $3 \mathrm{M}$ ha of coconut farmlands. In this regard, it is a fact that Malaysian oil palm farmers follow an effective and efficient crop nutrition management with a regular annual application of $3-7 \mathrm{~kg} /$ tree of NPKMg plus micronutrients fertilizer, while coconut farms in the Philippines are traditionally unmanaged (unfertilized), the main reason for the very low annual average yield of only $0.65-1$ ton copra per hectare.
\end{abstract}

\section{BACKGROUND AND SIGNIFICANCE}

Despite the strength of the Philippine Coconut Industry in terms of the area planted to the coconut crop (4 million has in 2001) producing 12 billion nuts annually from at least 300 million fruit-bearing trees spread over 50 major coconut-producing provinces, its annual productivity or yield (nut/tree or copra/ha) of 40 nuts ( $0.80 \mathrm{copra} / \mathrm{ha})$ is considered uneconomic and mismanagement of the huge land resource of the country.

To a great extent, many Philippine Coconut Authority (PCA) field studies and reports have revealed the widespread deficiencies of soil mineral nutrients (nitrogen, chlorine, sulfur, potassium, phosphorus) including micronutrients as boron, copper and zinc, and as a result of decades of coconut cropping without proper replenishment of these nutrients, there has been considerable

${ }^{1}$ Career Scientist IV, Department of Agriculture Philippine Coconut Authority Research, Development and Extension Branch, Diliman, Quezon City 1107, Metro Manila, Philippines. 
decrease in the harvested nuts. Moreover, soil losses (including soil nutrients) due to surface erosion, water runoff and nutrient leaching are significant causes of soil fertility deterioration and productivity decrease over the past 25 years, now affecting about 2 million hectares of coconut areas with pooryielding palms suffering from multi-deficiency in plant nutrients.

Soil Management and Plant Nutrition-based technologies generated by the PCA from 1972 to 1985 in correcting the nutritional deficiencies (chlorine, sulfur, nitrogen, potassium) effectively and efficiently or economically were implemented during the piloting of a coconut rehabilitation scheme under the SMALL COCONUT FARMS DEVELOPMENT PROJECT (SCFDP), 1990-1998, with a target of 350,000 has, nationwide (Table.1 and Figure 1). However, there were (around 50,000 ha.) areas which failed to achieve significant increase in nut and copra yield after 3 successive annual applications of single fertilizers supplying $\mathrm{N}, \mathrm{Cl}, \mathrm{S}, \mathrm{K}, \mathrm{P}$ and $\mathrm{Mg}$ ), and these areas are also likely deficient in micronutrients $(\mathrm{B}, \mathrm{Cu}$ and $\mathrm{Zn})$ as well, not supplied by the SCFDP fertilizers (Magat, 2000).

As most coconut areas in the country are suffering from multi-nutrient deficiency for macronutrients, secondary nutrients and micronutrients, to optimize the yields and economic benefits from an rehabilitation efforts, only multi-nutrient NPK fertilizers @ 2-3 kg/tree/yr, containing at least $15 \% \mathrm{Cl}, 5 \% \mathrm{~S}$ and $0.2 \% \mathrm{~B}$ (as borax) should be the general or ideal fertilizer for coconuts. In areas located inland and highly vulnerable to El Nino (intermediate and dry growing zones), application of additional 1-2 kg common salt (rock salt or unrefined sodium chloride) is strongly recommended. Together with these mineral fertilizers, the application of organic fertilizers like chicken manure and compost may be applied as a soil conditioner at least every other 2 years.

Table 1. Coconut Farm Productivity under SCFDP with Rehabilitation by Fertilization (19911995) and post-rehabilitation (1996-1998) and projected onwards (1999-2010) nationwide of 79 sample farms, covering 350,000 ha (1990-1998)

\begin{tabular}{|c|c|c|}
\hline Period & $\begin{array}{c}\text { Nut } \\
\text { (per tree/year) }\end{array}$ & $\begin{array}{c}\text { Copra } \\
\text { (ton copra/ha/year) }\end{array}$ \\
\hline Benchmark: 1991 & 35 & 0.94 \\
\hline SCFDP Rehab: 1992-1995 & 91 & 3.01 \\
\hline Post-Rehab: 1998 & 70 & 2.21 \\
\hline \multicolumn{3}{|l|}{ Onwards: } \\
\hline 1999 & 64.4 & 2.01 \\
\hline 2000 & 59.3 & 1.83 \\
\hline 2001 & 54.6 & 1.66 \\
\hline 2002 & 50.3 & 1.51 \\
\hline 2003 & 46.3 & 1.37 \\
\hline 2004 & 42.6 & 1.25 \\
\hline 2005 & 39.2 & 1.13 \\
\hline 2006 & 36.0 & 1.03 \\
\hline 2007 & 33.1 & 0.94 \\
\hline 2008 & 30.5 & 0.85 \\
\hline 2009 & 28.1 & 0.77 \\
\hline 2010 & 25.9 & 0.70 \\
\hline \multicolumn{3}{|l|}{ Note: } \\
\hline \multicolumn{3}{|l|}{ 1) $R$} \\
\hline \multirow{2}{*}{\multicolumn{3}{|c|}{$\begin{array}{l}\text { 2) Post-Rehab. average yi } \\
\text { 3) Onwards (1999-2010): }\end{array}$}} \\
\hline & & \\
\hline \multicolumn{3}{|c|}{ 4) Assuming no farming technologies, e.g. fertilization applied by farmers } \\
\hline
\end{tabular}


Even though, the Philippines is recognized as the biggest exporter of coconut products, particularly coconut oil, desiccated coconut, activated carbon and others, the country is considered a very unreliable and unstable in regular supply of coconut products due to yield fluctuations. Definitely, many uncontrollable negative factors are involved such as strong typhoons and El Niño (drought) occurrences. By and large the extensive very low standard of farming practices (about 2.5 million hectares) resulting in low production with fluctuations had undoubtedly caused bad international image which had remained over the past 2 decades or more? If it is continued this way for the next 5 years, there may be strong indications of a depressive outlook of coconut commodity including coconut oil in regional and international meetings of global coconut suppliers, marketers and product processors. The trust and confidence of the big and traditional buyers are likely to be lost soon if the industry has an unclear direction and workable plan to reverse the very low productivity of coconut compared to other lauric-rich vegetable oils (such as palm oil, rapeseed and others).

What then must be the logical and viable approach to the problem of unreliable or unstable coconut supply of the country? The only way is to make use of research-based technologies immediately within 3 to 5 years which are capable of optimizing the yields of the extensive areas (about 3 million ha) of our local tall varieties which are still the non-senile fruit-bearing coconuts. Replanting the senile palms with genetically superior varieties (talls, hybrids and synthetics) is a long-term activity with high investment cost, but should be done simultaneously with the rehabilitation of the current stands, as financial resources permits.

Under limited financial capability of the coconut industry, an extensive rehabilitation through fertilization (at 750,000 ha in 5 -years cycle, in 50 priority major coconut producing provinces in the wet and intermediate zones) is a logical priority in stabilizing the coconut supply at level of $3-4$ million tons copra/year within the next 5 to 10 years.

Significant findings and lessons during the government implementation of the SCFDP in the past years (briefly presented in this article) should be able to help in launching an extensive coconut rehabilitation program to save the Philippine Coconut Industry and its stakeholders as well as the Philippine economy in general, by maintaining if not strengthening its local, regional and global markets during the current decade and onwards. 


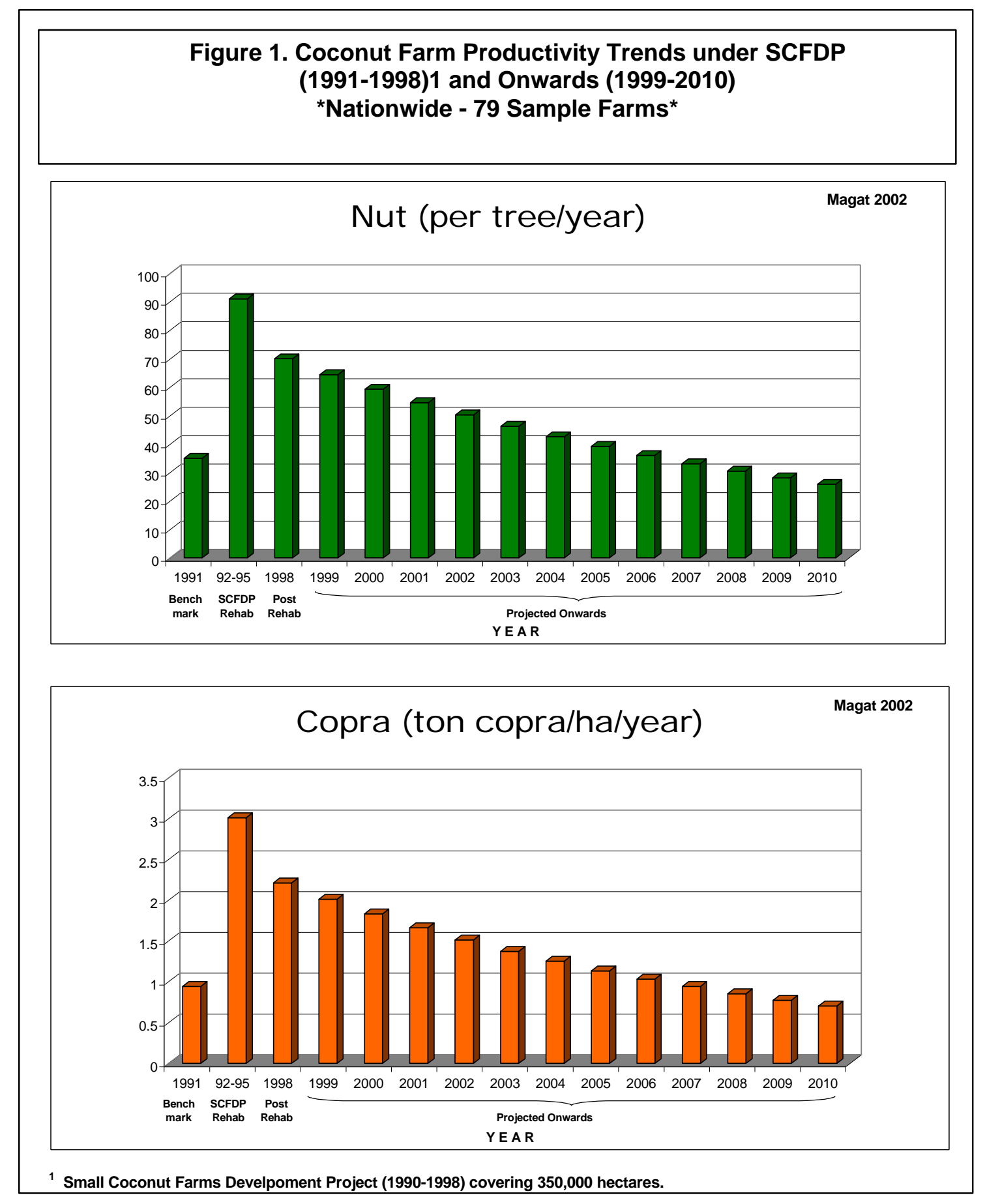




\section{Salient Findings and Lessons Learned from the SCFDP Years (1990 - 1998)}

In the preceding section, there are mentions of the strengths and weakness of the SCFDP piloting project, done by the government through the PCA, prior to launching of an extensive rehabilitation of poor-yielding non-senile palms in the country. In this regard, it is now a fact that in nutritionally-deficient coconut areas, the extent of the yield improvement $(50-150 \%)$ is achieved by judicious fertilization but other factors influenced the location-specific results, from year-to-year croppings.

\section{Salient Findings or Results Obtained (Table 1 and Figure 1)}

1. Benchmark or baseline average coconut productivity of farms is a low of 35 nuts/tree $(3,500$ nuts/ha.) at 100 trees per hectare or translated in copra terms of only 0.94 ton copra /ha based from the survey of 79 sample farms (5 regions, 9 provinces) as reported by Magat (1999), published in the APCC's Coconut Research \& Development J. (Vol. XV, No1).

2. After at least three years of regular annual fertilizer applications, the nut yield increased to an average of 91 nuts/tree/year(160\% increase), while the copra yield to 3.01 tons/ha/year $(220 \%$ increase). This clearly demonstrated the effectivity of fertilization to improve the marginal coconut yields (nuts and copra) of our extensively grown (around 300 million trees) tall varieties of coconut like Laguna Tall.

3. During the first three years of the post-rehabilitation period (1996-1998), yields dropped to 70 nuts/tree or 2.21 tons/ha/year, an annual yield reduction rate of $8-9 \%$. This average coefficient value is used to predict the yields in the coming years up to 2010 (medium range).

4. As the previous fertilizer applications provided positive residual effects on coconut production for the ensuing years, farm yields are predicted to reach the low baseline yields similar to that of 1991 in 2006 (nut terms) and in 2007 (copra terms). This means the soil fertility levels (available soil nutrients for the crop) has returned to the deficiency levels of 1991, producing only 35 nuts/tree or 0.94 copra ha.

5. Without fertilizer applications since 1998, the projected consistent decline in coconut productivity will likely reach a very dismal 26 nuts or 0.70 tons copra by the year 2010 . And beyond, predicted worst, if no rehabilitation efforts are firmly instituted.

6. Even in highly adequate rainfall years $(2000 \mathrm{~mm}$ rainfall/yr) in which the positive effect of rainfall increases the average farm annual yields by $12-30 \%$ in the intermediate and wet growing zones (SCDFP-CYA: Report No 1/96, Davao City), an additional 4 nuts or $2 \mathrm{~kg} /$ tree ( $0.20 \mathrm{t}$ copra) per year could be gained by farms. But certainly, the consistent decline in soil nutrients and the cyclical El Niño could easily masked off the rainfall advantage. In fact, many workers had claimed that fertilization, particularly, the application of chloride-based fertilizers as $\mathrm{NaCl}$ (common salt) and potassium chloride protects coconut yield from the depressive and devastating impact of very long and hot dry periods in the Philippines and Indonesia.

\section{Implications of Findings on the Philippines Coconut Productivity Directionsd}

In 2000, Malaysia produced 10.70 million tons of palm oil plus 1.42 million tons of palmkernel oil (lauric-rich oil like coconut oil) from its 2.91 million ha. of oil palm crop, while Indonesia produced 6.65 million tons plus 0.67 million ton of palm-kernel oil from its 2.01 million ha. of oil palm crop. In contrast, in the same year the Philippines produced only 2.54 million tons of coconut (in copra terms) from its 3.1 million hectares. 
The globally-known success of Malaysia in pushing the level of production and productivity of oil palm to high average of 3.8 tons palm oil/ha./year of the widely planted tenera hybrid material (24 -32 tons fruit-bunch/ha./year) is strongly due to its effective and efficient crop nutrition plantation practice with the regular annual application per tree of 3-4 kg NPKMg fertilizers plus micronutrients (Hardon,Rajanaidu and van der vorssen, 2001). In this manner, the genetic potential of the oil palm crop is optimized, making it a very efficient vegetable oil crop ( $3.5-5$ times higher than coconut). Under the traditional farmers' practice (unmanaged), the average oil yield is only $0.65-1$ ton /ha/year, very unattractive under commercial farming.

The Philippine SCFDP experience years back (based from piloting of 350,000 ha.) as strongly showed in table 1 and figure 1, provides us a clear understanding that the 3 million ha of fruit-bearing coconuts could be made economically productive, thereby practically placing the coconut industry as a globally stable and reliable supplier of coconut in $3-5$ years $(750,000$ ha. every 5-year cycle) through a sustainable judicious fertilization of coconut farms.

For the country to be a confident and consistent supplier of coconut at the level of 3-4 million tons copra, annually, the country's farm productivity should be within 72 to 96 nuts/tree/year and this could be achievable in the most of the wet and intermediate growing zones (at least 2 million ha.) via application of multi-nutrient fertilizers at moderate and economic rate of application, costing P $1,750-2,500$ per ha./year.

With high farm productivity of at least 90 nuts or 3 tons copra /ha. year and a satisfactory copra price of at least 10 Phil. Pesos per $\mathrm{kg}$ copra, production cost should be lower (not more than P 5.50), and net income is expected to be more than P 15,000/ ha. /year from coconut alone. In addition, marketable high value intercrops which benefit also from proper nutrition management could generate total annual net farm income of Phil. Peso 25,000-50,000 per hectare.

Without crop nutrition management, that is, coconut farmers leaving their coconuts to the nutrient supplying capability of our impoverished and degraded soils, in year 2010, coconut farms would be more marginalized, producing only a very uneconomical 25 nuts/tree/year or 0.70 ton copra/ha /year.

The worst scenario, our international buyers would likely have shifted to more reliable producers of coconut or to other vegetable oils. With the very coconut weak industry in the next 10 years, it is bound to collapse because we ignored the lessons of the SCFDP that a coconut rehabilitation through judicious fertilization of the extensive non-senile palms is economically viable, provided farmers are technically and financially supported. In fact, earlier survey of the impact of SCFDP revealed that small coconut farmers though interested to apply fertilizers to increase farm productivity are not capable of investing in fertilizers on their own, a sad reality under Philippine conditions.

As strongly stressed and emphasized in this presentation, our coconut farms are largely inefficient (a major cause of the country's unreliable supply of coconut) because we have intensely failed to feed our nutritionally-deficient 250 million coconuts properly and timely. The inadequate and imbalance levels of soil nutrients in the coconut areas must be corrected soon, and judicious fertilization is a must.

As a concluding remark, the Malaysian Success is based on very sound and economically viable integrated crop management (ICM), by optimizing the genetic potential yields of oil palms through sustained investment in balanced crop nutrition, from field-planting up to fruit-bearing stage and onwards. 


\section{CONCLUSION}

1. Hence, for the coconut industry to survive as a globally competitive industry, a substantive and reliable source of coconuts ( $3-4$ million tons per year, in copra terms), providing food and environmental benefits, livelihood to a third of Philippine population and generating desired financial resources for its human and economic development, the Government must plow-back at least $10 \%$ of its foreign exchange earnings (P 4 billion year) from exported coconut products as its annual investment in crop nutrition management of our over 3 million hectares of coconut farmlands.

2. The Government should help (financially and technically) our resource-limited farmers (at least 1.5 million) harness or gain the annual incremental yield of 40-50 nuts or 1- 1.5 tons copra/ha they have been deprived of for several decades due to the multi-nutrient deficient soils in their farms, requiring immediate and practical balanced fertilization.

\section{REFERENCES}

Bonneau, X., D. Boutin, R. Bourgoing, and J. Sugarianto. 1997. Sodium chloride, an ideal fertilizer for coconut palms in Indonesia. Plantations: Res, Dev. 4(5):336-346.

Hardon, J.J., N. Rajanaidu, and H.A.M. van der Vossen. 2001. Oil palm (Elaeis guineensis Jacq.). In: van der Vossen, H.A.M. and Umali, B.E. (Editors): Plant Resources of South-East Asia No 14. Vegetable oils and fats. Backhuys Publishers, Leiden, the Netherlands. pp.85-93.

Ohler, J.G. and S. S. Magat.2001. Coconut (Cocos nucifera L.). In: van der Vossen, H.A.M. and Umali, B.E. (Editors): Plant Resources of South-East Asia No 14. Vegetable oils and fats. Backhuys Publishers. Leiden, the Netherlands. pp. $76-84$.

Magat, S. S., R.Z. Margate, and J.A. Habana. 1988. Effects of increasing rates of sodium chloride (common salt) fertilization on coconut palms grown under an inland soil (Tropudalfs), of Mindanao, Phi-lippines. Oleagineux. 43(1): 13- 20.

Magat, S.S., G.D. Padrones, and L.M. Alforja. 1993. Residual effects of three chloride fertilizers on yield and leaf nutrient levels of coconuts grown on an inland soil of Davao (Mindanao,Philippines). Oleagineux

48 (5): 237-241.

Magat, S.S. 1999. An Assessment of the Post-rehabilitation (Fertilization) of coconut in SCFDP Farms, Philippines. Coconut Res. Dev. J. 15 (1) : 1 - 19.

PCA-Region XI. 1996. Coconut Rehabilitation by Fertilization Component: Coconut Yield Assessment. A Report, The Small Coconut Farms Development Project (SCFDP) of the Philippines (WB-PH-3204). SCFDP - CYA: Report No.1/96. Davao City. 72 p.

UCAP. 2001. Coconut Industry Kit: Series of 2002. Ortigas Center, Pasig City, M. Manila. 50p. 